\title{
Emergency Messaging to General Public via Public Wireless Networks
}

\section{P. Simonsen and L-F Pau}

\begin{tabular}{|l|l|}
\hline \multicolumn{2}{|l|}{ ERIM REPORT SERIES RESEARCH IN MANAGEMENT } \\
\hline ERIM Report Series reference number & ERS-2007-078-LIS \\
\hline Publication & November 2007 \\
\hline Number of pages & 11 \\
\hline Persistent paper URL & http://hdl.handle.net/1765/10718 \\
\hline Email address corresponding author & Ipau@rsm.nl \\
\hline Address & Erasmus Research Institute of Management (ERIM) \\
& RSM Erasmus University / Erasmus School of Economics \\
& Erasmus Universiteit Rotterdam \\
& P.O.Box 1738 \\
& 3000 DR Rotterdam, The Netherlands \\
& Phone: + 31 10 408 1182 \\
& Fax: + 31104089640 \\
& Email: info@erim.eur.nl \\
& Internet: www.erim.eur.nl \\
\hline
\end{tabular}

Bibliographic data and classifications of all the ERIM reports are also available on the ERIM website: www.erim.eur.nl 


\section{ERASMUS RESEARCH INSTITUTE OF MANAGEMENT}

\section{REPORT SERIES}

\section{RESEARCH IN MANAGEMENT}

\begin{tabular}{|c|c|}
\hline \multicolumn{2}{|c|}{ ABSTRACT AND KEYWORDS } \\
\hline Abstract & $\begin{array}{l}\text { Warnings to the broad population in an emergency situation, irrespective of location and } \\
\text { condition, is a public policy responsibility. Public wireless networks offer now the opportunity to } \\
\text { deliver emergency warnings in this way with explanations, because in many countries the mobile } \\
\text { penetration rates are higher than any other access form. The paper summarizes the analysis of } \\
\text { the selection process between Short messaging services (SMS) and Cell Broadcast messaging } \\
\text { in the context of Denmark based on end user requirements and stakeholder roles. It } \\
\text { demonstrates the many technical, cost-benefit and other trade-offs needed in supporting the } \\
\text { population now with a dependable and wide-spread technology. }\end{array}$ \\
\hline Free Keywords & public wireless networks, emergency warnings, SMS, cell broadcast (CB) \\
\hline Availability & $\begin{array}{l}\text { The ERIM Report Series is distributed through the following platforms: } \\
\text { Academic Repository at Erasmus University (DEAR), DEAR ERIM Series Portal } \\
\text { Social Science Research Network (SSRN), SSRN ERIM Series Webpage } \\
\text { Research Papers in Economics (REPEC), REPEC ERIM Series Webpage }\end{array}$ \\
\hline Classifications & $\begin{array}{l}\text { The electronic versions of the papers in the ERIM report Series contain bibliographic metadata } \\
\text { by the following classification systems: } \\
\text { Library of Congress Classification, (LCC) LCC Webpage } \\
\text { Journal of Economic Literature, (JEL), JEL Webpage } \\
\text { ACM Computing Classification System CCS Webpage } \\
\text { Inspec Classification scheme (ICS), ICS Webpage }\end{array}$ \\
\hline
\end{tabular}




\title{
Emergency messaging to general public via public wireless networks
}

\author{
P.Simonsen, Accenture Denmark; L-F Pau, Rotterdam school of management
}

\begin{abstract}
Warnings to the broad population in an emergency situation, irrespective of location and condition, is a public policy responsibility. Public wireless networks offer now the opportunity to deliver emergency warnings in this way with explanations, because in many countries the mobile penetration rates are higher than any other access form .The paper summarizes the analysis of the selection process between Short messaging services (SMS) and Cell Broadcast messaging in the context of Denmark based on end user requirements and stakeholder roles . It demonstrates the many technical, cost-benefit and other trade-offs needed in supporting the population now with a dependable and wide-spread technology.
\end{abstract}

\section{INTRODUCTION}

In many countries of the world (developped as well as emerging), the basic emergency warning system to the broad population is still acoustic, with a network of static or moveable horns activated by the public authorities and ranging to groups of inhabitants in order to achieve a high coverage .A variant thereof is acoustic messaging via the radio or possibly multimedia based warnings via the public TV networks. There is however still a long way to go before Internet fixed access points, alike TV sets , will be always-on and reach a large fraction of the general population, till such acoustic warning systems will be made entirely obsolete ; the implied costs born by the users from Internet or TV access, work patterns, , mobility , as well as social factors such as age , handicap ,connection behaviours , will together and for a while still prevent rather sizeable parts of the population from getting warned by Internet or TV alone when suddenly needed .

Separately , the critical analysis of public emergency situations all highlight the huge need for post-event information updates to be distributed in real time to the general population or selectively , whether people are exposed or not to the hazards , to ease rescue , evacuation , reduce panic levels , or for other tasks .Furthermore, at such post-event stages, central alarm notification is not enough ,as individuals and groups need to communicate with other individuals or support points in a personalized way. This speaks in favour of personalized messaging [1].

Finally, warning as well as post-event communication via resilient and redundant infrastructure, should not flood communication capacity,especially if this has been reduced due to the events. Also it is not at all advised that the access terminals be made special, except for unique situations (lonely blind people, polytraumatic disabled persons etc).

\section{SCOPE AND BACKGROUND}


This research therefore has first been triggered by the concept of using widely adopted modern ubiquitous personal communications and messaging facilities such as those offered by public wireless networks. Whereas wireless networks such as those based on TETRA have the same properties, they are conceived and used as a private networks usually by the public authorities themselves, and very little discussion has taken place as to giving equivalent capabilities to the general public itself .It should be highlighted that thanks to licensing requirements set by the national or multinational regulators, very high geographical coverage is granted in many countries, and wireless terminal penetration is, if not 100 $\%$ of the population, then vastly larger than fixed Internet access points with 3 Billion users worldwide in 2006 .

The research has also been triggered by flaws found in Denmark by special interest groups in terms of the warning systems coverage in space and time, with the corresponding political and media outcry resulting from such issues being brought to the limelight .It was found that, after everything else possible had been done, there would still in Denmark be one out of thousand individuals, especially hearing impaired, who could not be warned with the planned national emergency resources [2]. Even if the terrain is not the issue in Denmark, just because of life behaviours, at any time 1/5 of the population are outside the range of the acoustic horns or not able to listen to radio/TV [2] .Also, it was found that over $60 \%$ of the population nowadays does not know the meaning of the emergency horns signals or do not react to them, as evidenced by the large flow of requests to emergency numbers after routine tests.

The scope of this paper is to summarize the findings of a project driven by emergency scenarios and cases, which specifies how .public wireless networks can in the present situation at short notice enhance and possibly replace legacy warning systems to the general public while satisfying public interest and fast deployment requests [3] .More precisely, were investigated in depth the operational , technical , cost-benefit and immediate availability aspects, of public emergency messaging via SMS or Cell Broadcast standard technologies in 2G and 3G wireless networks. Was also evaluated the use of Mobile Internet, but limitations in the installed base of wireless terminals and/or user acceptance and familiarity, lead to its exclusion .

Some alternatives have been identified, such as the use of the electrical power networks, DVB-H, DBM (China), digital radio, wireless LAN hot spots, or Internet access via set-top boxes, but all were quickly disqualified for lack of penetration in the population, or incompatibility with life behaviours in view of alarm coverage and user mobility.

More precisely, if the following classification of public warning systems is considered:

Type A: general warning of the largest possible part of the population in real time (such as by acoustic horns)

Type B: general warning and information of the largest possible part of the population in quasi real-time (such as via radio or TV broadcasts)

Type C: personalized message based warning and information of the largest possible part of the population in real time

Type D: personalized message based warning and information, of specific population groups in real time (such as via fixed Internet messaging, TETRA or deaf /blind specific solutions) 
, then the focus of this research has been on Type $\mathrm{C}$ solutions for short term deployment .The sensor and information fusion aspects for higher dependability or resilience, and better validation, can still be derived from the co-existence with other Type A,B or D systems .

\section{WIRELESS MESSAGING TECHNOLOGIES}

Short messaging service (SMS) [4] allows to send in its simplest form up to 164 characters from any terminal or central node, to any single mobile subscriber, in a point-to-point manner with store-andforward best effort delivery via SMSC (SMS Center) nodes .Enhanced SMS offers greater lengths but are exposed to much higher transmission costs; IMS messaging as standardized under 3GPP allows for very large lengths and embedded multimedia but is not much deployed yet. Cell Broadcast $[5,6]$ is also a messaging system which allows to send in one go 93 characters from any central node, or application linked to it, to all mobile users satisfying common selection criteria; this is carried out in a point-tomultipoint manner with small delays via the CBC (Cell Broadcast center) .Cell Broadcast also is unique in allowing up to 15 messages to be linked together so that they appear together once all received, i.e. in total 1395 characters

In Denmark there were in early 2007 5,4 Million GSM wireless subscribers, and 200000 3G subscribers, all using services compliant with the 2 nd generation GSM standards and their UMTS evolution (3GPP1 ). Short messaging systems (SMS) and Cell Broadcast are both mandated parts of the GSM and UMTS standards, and specified by ETSI [4]. As a result, in principle, both SMS and Cell Broadcast messaging services are supported in the firmware or middleware of the handsets. Whereas SMS services enjoy a phenomenal boom and represent huge revenue to the public operators, with in average about 1000 SMS messages/subscriber/year, many operators decided very early on never to deploy and support Cell Broadcast services because of lack of commercial service revenues. Geographical coverage is $99 \%$ of the country (except in Greenland)

\section{DECISION MAKING PROCESSES AND METHODOLOGY}

The adoption of messaging based systems for public emergency warnings is a national policy decision as it falls under government's decision to handle public safety. However because of the investment costs and even larger operating costs, and because of the low likelihood of the systems providing a payback as events are rare, such decisions are hard to get. On the other hand, the emergency system operators have to be neutral and positioned in such a way institutionally and legally to be able to receive all data and information needed for warning and post-event messaging, while they also must have the trust of public and government alike . Finally, the system subcontractors, such as public wireless operators , may not see at all a business case in maintaining a high degree of resilience and availability at all times, combined with randomly high traffic at event times .However, in such countries as Denmark, provisions were put in the mobile operator license conditions to mandate help with services of public interest , although terms and conditions had to be negotiated from case to case .It is thus necessary to take a public-private partnership business model in the role distribution and the corresponding funding schemes .

From the above description of the decision making process, the following recursive filtering and elimination methodology had to be applied: 
1) Scenario analysis to characterize the range of alarm situations to be handled short-term by a wireless messaging system ,on the basis of the threat categories from the Emergency Directorate [2].

2) End user requirements on performance and other attributes for each scenario, and satisfaction of these requirements when the warning messaging is delivered to them using the two alternative technologies; the survey method was used to elicit the requirements so these data are primary data; secondary data are the results of the ETSI "Emergency service and civil protection communities” (www.emtel.etsi.org ).

3) Engineering analysis of traffic and congestion implications.

4) Validation of the requirements from 2) from post-event debriefs from past catastrophes in Denmark and abroad, and subsequent reconciliation; such debriefs are secondary data; the two selected debrief cases are first the London terrorist bombings on 07 July 2005, and next the huge fireworks factory explosion in Seest, Denmark on 03 November 2004. Further validation details and sources are found in [3].

5) Stakeholder cost-benefit analysis of all key parties involved in the decision and operations: Information and Communications regulator ("IT \& Telestyrelsen”) Emergency Directorate (“Beredskabsstyrelsen”), National Police (“Rigspolitiet”), Local Police , Police warning center (“Alarm centralen Århus”), wireless public operators (incl. TDC A/S). This analysis also involved interviews and calculations.

6) Stakeholder risk analysis for all key parties involved, this time including the end users.

The steps 5) and 6) involved 18 structured interviews supplemented by validation questions all representing primary data. Interaction has also happened with ETSI, the Cell Broadcast Forum, and CEASA which is the body specializing in warning networks with use of Cell Broadcast technology.

\section{WARNING OR ALARM PROCESSES}

There is a differentiation between zone of operations and event location; the rescue team operates at the location of the event and has the leadership; the zone of operations encompasses a whole range of support functions (such as temporary placements for wounded persons etc) and the leadership is here by the Police. Normally, the decision to issue a warning or alarm resides with three organizations:

i. the head of the zone of operations,

ii. the head of the event operations, and

iii. the head of the Police district

The need to alarm goes from i. to ii. with information about the event location and type, and after feedback and confirmation to iii. who orders the public alarm via the Central alarm center. There are however exceptions where i. can request the alarm from iii. without validation, just like the watch officer in iii. can activate the alarm in extreme situations where there is not enough time to run the normal procedure. In general i. formulates the alarm message, although it may be iii. in extreme situations.The above communication is today by telefax for legal reasons, with telephone back-up and a back-up alarm center in Slagelse as well. A governmental Internet VPN will also be used.

As it is now, the watch officer at the Central alarm center in Århus (or Slagelse) activates the horns in the zone of operations, enters the warning message in the alarm system, from which it is sent to the national broadcasters DR and TV2 who produce radio/TV/Text-TV readouts, as well as a copy is sent the Emergency Directorate and the national wire service Ritzau..

It is also allowed for the state or municipal authorities ("Kommune”) with emergency handling resources to issue alarms ; for the state authorities they go directly to the national alarm center in Århus, while for the others they must go via the relevant Police district .The alarm messages have a fixed 
format [2] on status category, source, contact, reason, who should be warned, needed actions by these persons, timing for possible signals, and possible early warning about timing for the next possible messages. The warning messages analyzed in the project had an average length of approx. 1000 characters ,largely because of specific orders to receivers (evacuation , physical protection, routes etc) ; this length is in general too long to display on most mobile terminal displays ,thus the project has recommended to send out a short version first .

\section{REQUIREMENTS VALIDATION FROM CASES}

The London case demonstrated a 2, 5 hours delay between the first bomb explosion at 08:50 and the first message by the London Commissioner of Police of the Metropolis, Sir Ian Blair, at 11:15 to "go in, tune in"; this was later criticized in the July 07 Review committee report [7] .The Web content on BBC referred mistakingly to electrical surges as the events. Phone calls could not be made as the networks were cut or overloaded by a factor of about ten [7].Individuals alerted others by email about the bombings from 09:30. Vodafone tells it considered sending out 15 Million SMS messages as a warning but gave up due to the added congestion and delay .City of London Police asked the wireless operator $\mathrm{O} 2$ to activate access overload control (ACCOLC) in a zone of $1 \mathrm{~km}$ around the subway stations affected by the attacks ,meaning only phones with special SIM cards could use the network for about 5 hours .,and $\mathrm{O} 2$ lost several hundred thousand calls .Many people were at work or on their way, and with no access to TV , so that lack of information made people insecure .

The Seest case [8] involved a fire in the N.P. Johnsen fireworks manufacturing plant in the town of Seest in Denmark; the fire was enormous and the zone of operations had to be enlarged twice due to the broadening of all explosions .One thousand people were wounded or evacuated, on fireman died, 60 houses were burnt down totally as well as 8 fire fighting vehicles. The alarm horns were activated twice and the broadcast network DR also, 3 minutes after the second explosion, then the second 3 minutes before the largest explosions who could be heard more than hundred kilometres away .Panic spread rapidly in the population and the Police used loudspeakers from vehicles to request evacuation .The Police recognized later that the warnings by horns were not heard or understood by most people. Police had to run from house to house to request to go to a school and register there. Detailed explanations were first found next morning on the Kolding's municipality's Web site and by the radio network DR Channel 94.During this event, the health emergency services, the firemen, the municipality's emergency resources as well as Police, all relied on the public wireless network using mobile virtual private networks in use by each party on a routine basis. The population also used the same network but with public access .It was reported that while some redialling was needed, all users got access to the network within short time ,and access overload control was never used ;blocking probability was also low thanks to the way the local base station network and BSC had been configured in the area .

\section{USER REQUIREMENTS AND SATISFACTION BY SMS or CELL BROADCAST MESSAGING}

The main user requirements, resulting from Steps 1-4 in the methodology Section above, are identified in the second column of Table 1. The results of Steps 2 and 3 in terms of the extent to which these requirements are met by SMS and Cell Broadcast messaging services are featured in summary form in the two right hand columns; extensive analysis is provided in [3]. 


\begin{tabular}{|c|c|c|c|}
\hline Number & User Requirement & SMS satisfaction & $\begin{array}{l}\text { Cell Broadcast } \\
\text { satisfaction }\end{array}$ \\
\hline 1 & $\begin{array}{l}\text { The messages must include both warnings and } \\
\text { orders ,and they must be formulated in an easy } \\
\text { understandable language }\end{array}$ & $\begin{array}{l}\text { Partially as SMS } \\
\text { messages are too } \\
\text { short }\end{array}$ & Yes \\
\hline 2 & $\begin{array}{l}\text { The alarms messages must be up-to-date, with } \\
\text { possibly three categories: instant alarms , } \\
\text { growing visible event occurrence , and } \\
\text { expected sudden occurrence }\end{array}$ & Yes & Yes \\
\hline 3 & $\begin{array}{l}\text { Messages must be able to be sent in several } \\
\text { languages for residents and tourists }\end{array}$ & No & Yes \\
\hline 4 & $\begin{array}{l}\text { The warning messaging system should not use } \\
\text { any extra memory, battery or computational } \\
\text { power on the access terminals ,and thus } \\
\text { multimedia messages including MMS are } \\
\text { excluded }\end{array}$ & Yes & In general yes \\
\hline 5 & $\begin{array}{l}\text { Only the population in the zone of operations } \\
\text { and other threat areas must be warned , } \\
\text { meaning geographical filtering is required ; } \\
\text { filtering must be from exact mapping data and } \\
\text { not just from location names }\end{array}$ & $\begin{array}{l}\text { Partially as SMSC } \\
\text { is normally not } \\
\text { linked to cell } \\
\text { locations }\end{array}$ & Yes \\
\hline 6 & $\begin{array}{l}\text { Irrespective of the situation and user numbers, } \\
\text { the maximum delay from the warning } \\
\text { command time to receipt by end users, should } \\
\text { be max } 5 \text { minutes }\end{array}$ & $\begin{array}{l}\text { No, unless small } \\
\text { teledensity and } \\
\text { zone size }\end{array}$ & $\begin{array}{lr}\text { Yes, unless too large } \\
\text { population } \\
\text { insufficient } \\
\text { capacity }\end{array}$ \\
\hline 7 & $\begin{array}{l}\text { The public warning system must operate in the } \\
\text { whole country with all } 2 \mathrm{G} \text { and } 3 G \text { public } \\
\text { operators }\end{array}$ & $\begin{array}{ll}\text { Yes } \quad(99 & \% \\
\text { geographical } & \\
\text { coverage } & \text { in } \\
\text { Denmark }) & \end{array}$ & $\begin{array}{ll}\text { Yes } \quad(99 & \% \\
\text { geographical } & \\
\text { coverage } & \text { in } \\
\text { Denmark) } & \end{array}$ \\
\hline 8 & $\begin{array}{l}\text { The public warning system functionality must } \\
\text { be supported in the firmware or middleware of }\end{array}$ & Yes & Yes \\
\hline
\end{tabular}




\begin{tabular}{|c|c|c|c|}
\hline & all 2G and 3G wireless handsets & & \\
\hline 9 & $\begin{array}{l}\text { All persons on danish soil with a GSM or } \\
\text { UMTS terminal must receive the warning } \\
\text { messages without registering for the service } \\
\text { and without specific terminal configuration }\end{array}$ & Yes & $\begin{array}{l}\text { No , unless Cell } \\
\text { Broadcast } \\
\text { configuration done } \\
\text { beforehand }\end{array}$ \\
\hline 10 & $\begin{array}{l}\text { The messaging system must include a training / } \\
\text { exercising functionality and include provisions } \\
\text { to distinguish alarm messages from normal text } \\
\text { or MMS messaging }\end{array}$ & Yes & Eventually \\
\hline 11 & $\begin{array}{l}\text { Operations should not be affected when Access } \\
\text { overload control ,call gapping or other QoS } \\
\text { features are activated }\end{array}$ & Partially & Yes \\
\hline 12 & $\begin{array}{l}\text { The system should be free of charge for end } \\
\text { users, and operators should not charge } \\
\text { specifically for warning messages; legislation } \\
\text { to be introduced to enact the system under } \\
\text { universal service obligations }\end{array}$ & $\begin{array}{l}\text { Yes within tariff } \\
\text { bundle limits }\end{array}$ & Yes \\
\hline 13 & $\begin{array}{l}\text { Deaf / blind and severely physically / mentally } \\
\text { disabled persons should be warned by the same } \\
\text { system, with possible additional user interfaces }\end{array}$ & Yes & Yes \\
\hline 14 & $\begin{array}{l}\text { The system should be secure and trusted with a } \\
\text { central information control }\end{array}$ & Yes in general & Yes \\
\hline 15 & $\begin{array}{l}\text { No single point of failure in process, hardware, } \\
\text { software or communications may exist }\end{array}$ & Yes & Yes \\
\hline 16 & $\begin{array}{l}\text { All issued warning messages, destination } \\
\text { groups and times must be logged }\end{array}$ & Yes & Yes \\
\hline 17 & $\begin{array}{l}\text { It should be legal to build and deploy the } \\
\text { system ,and regulatory approval must be } \\
\text { established }\end{array}$ & Yes & $\begin{array}{l}\text { Yes, but operators } \\
\text { have not activated } \\
\text { the service in general }\end{array}$ \\
\hline
\end{tabular}


Table 1: Summary of end user requirements for wireless emergency messaging, and satisfaction thereof by SMS and Cell Broadcast services

Template messages must be designed to both speed up the actual editing in a specific situation, and also to help in training /exercising .An example is provided in Figure 2.

Category: Building fire

"WARNING by Police:

A fire in (location) now produces poisonous gases: You are now in an area which this dangerous smoke may cross. Go indoors, close doors / windows / ventilators .Indoors the risk will be much reduced. Listen to DR and TV2 for more information. You will receive an update on your mobile phone when (danger is over / danger is worsened / evacuation is ordered / other).

Police Chief in (location)

Figure 2: Example of template message (translated from Danish); length in Danish is 366 characters at most

\section{ALARM SITUATION CONGESTION TRAFFIC ANALYSIS}

A full calculation model has been developped whereby Radio base system (RBS) , Base system controller (BSC) and SMSC or CBC capacities over time are determined, assuming nominal capacities in signalling, storage and message traffic intensity; such capacities are specifically determined when loaded by emergency wireless messaging requests While the traffic analysis relies on standard wireless network traffic engineering (with circuit switched connections over the air interface as in 2G and 3G), the calculation is unique to emergency situations because it is time dependent and recursive .

The driving process is a person-to-person social communication network, evolving over time for a given wireless teledensity in the surroundings. At alarm time, the wireless traffic load is equal to the number of detected users in the zone of intervention or its overlapping RBS coverage area; this is determined by the active signalling channels to these RBS'es. Post alarm, any given user is assumed to call or message on behalf of other users: family, work, transportation assistance, health assistance. By an obvious snowball combinatorial explosion effect, each of these four message receipients from any given warning person will again generate an average of three messages or calls, of which 2 back to the person in the zone of operations. The process is set to repeat itself, at time intervals linked to an emergency event category, and once again at the possible receipt of an updated warning message from the public authorities.

Congestion happens whenever: either the calculated blocking probability exceeds some specified threshold, or when an infrastructure node is saturated because of its capacity (including on the number of active signalling channels), or when the message queue waiting length exceeds the max. 5 minutes requirements criterion. 
While the full details are too extensive to be specified here, this analysis allows statistically to determine which of SMS and Cell Broadcast give congestion the last, meaning the system can be up and running longest (by either of thr three congestion reasons above) .SMS is shown to be strongly subject to queuing congestion except if the zone of operations has a low teledensity . A different complementary analysis method is described in [9]. The Cell Broadcast messages are sent out on the $\mathrm{CBCH}$ Cell broadcast channel without interference from the voice traffic, unless signalling capacity is limited [5]. The effect of the RBS network planning focussing on an ideal mesh distribution is analysed in [10] while the reality of the uneven RBS location priorities of operators for the Danish capital and the Seest disaster area are illustrated in Figure 3. RBS location mismatch to latent user teledensity is another additional negative factor which however was not studied in this research.
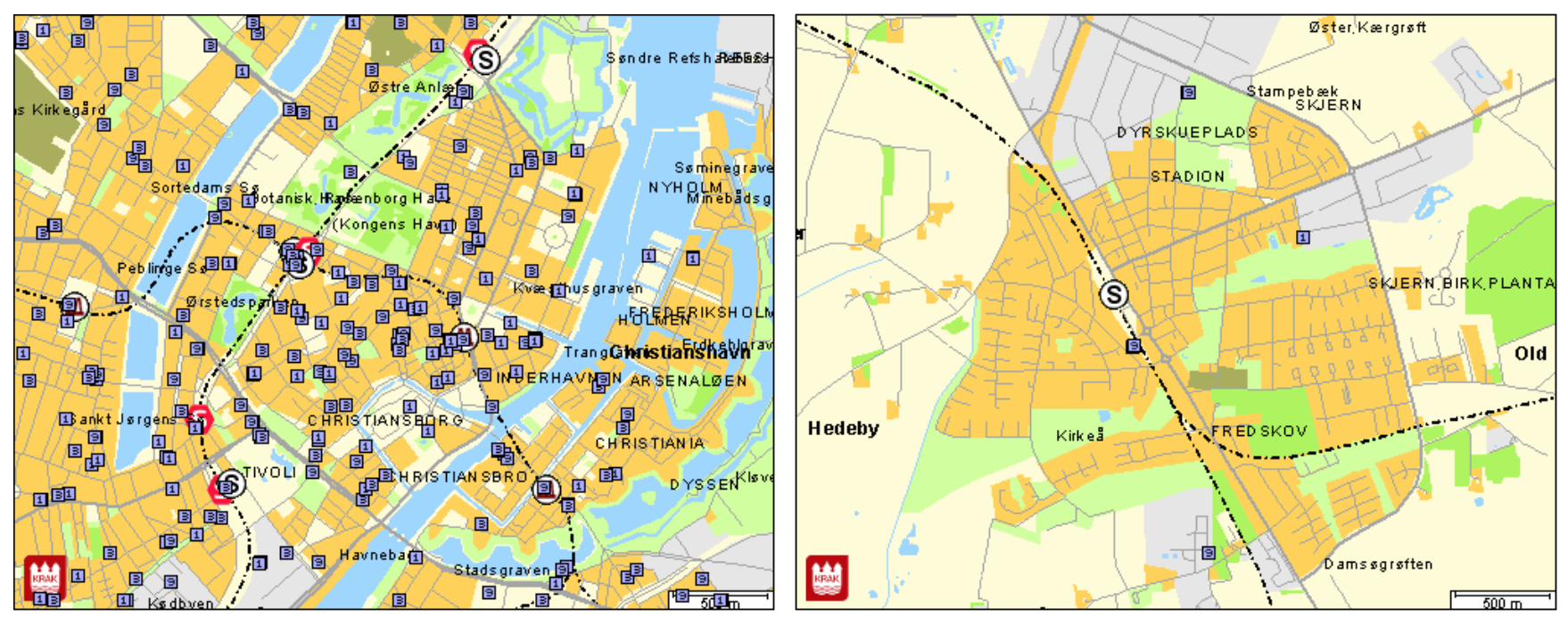

Figure 3: RBS locations in Copenhagen and Skjern area (close to Seest disaster) Source: www.mastedatabasen.dk ; the locations are marked with a grey cube 目 with a number or letter label

\section{COST BENEFIT and RISK ANALYSES}

The risk analysis has been carried out by estimating for each identified event / risk category, a value at risk, and the corresponding probability ; a risk priority ranking is derived by taking the product of these two numbers [3] .Are determined to be factors with the highest risk: the overload of the networks ,the fact that most public operators see Cell Broadcast as an irrelevant or not profitable technology with little compensation by the public authorities, the rarity of warnings, and the fact that the warning system implementations are not flexible enough for highly diversified risks .

The cost-benefit analysis [3] forms the basis for a decision by policy makers about a wireless emergency network but is based on a range of assumptions and estimates which need to be revised in each concrete situation .SMS and Cell Broadcast emergency messaging both represent incremental investments and operational costs to existing GSM or 3GPP1 networks ; this is a favourable factor for fast adoption as the underlying basic infrastructure is already in place thanks to mobile operator investments . While 3G may overtake GSM in the longer term as featured in [11] , the short term reality is that GSM is dominant . One cost-benefit assumption is that there are in average two emergency situations per year per zone of 
operations with an average of 200000 inhabitants or guests, and that three warning messages are sent out each time (warning, post-event instructions, and end of warning); such values correspond to the average use of the horn based systems over the past 10 years [2] ; the majority of the emergency situations are assumed from past data to be linked to dangerous smoke, water poisoning or dangerous gas. Parametric cost-benefit assumptions deal with the benefits impact of each warning message in reducing the death count, severe injuries and light injuries by multiples of $1 / 2,5$ and 20 persons respectively. Data are also used from the Transportation and Energy Ministry [12] about person related losses and general welfare losses for each death, major or light injury. The cost benefit present value calculation horizons are 5 or 15 years (to match residual GSM or 3GPP1 license durations) with a discounting factor of $3 \%$.

The net present value of an SMS based emergency messaging warning system is always negative and in average about 4 times more affordable than the one for a Cell Broadcast based solution; also, the SMS based solution alone offers positive net cash flow except at incremental investment time (see full details in [3]) .The analysis also allows to determine the hypothetical break even situations needed to recover system investments and operating costs ; for SMS messaging the needed reductions in number of deaths are at least 12 persons (for 5 years) and 18 persons (for 15 years) ; for Cell Broadcast messaging, the equivalent numbers are 31 and 54 persons .

In summary this means that public network based emergency warning systems are strictly speaking both loss-making investments because they still do not allow in general to reduce fast enough the number of deaths and injuries. However, the SMS based solution is still the most favourable and affordable from a public benefits point of view for the normal emergencies encountered in Denmark and the possible reductions of losses within the population thanks to the corresponding wireless warnings seem to be achievable much faster than with Cell Broadcast.

\section{CONCLUSION AND FURTHER WORK}

This research has explored the short-term opportunity offered by leveraging on existing widely used and accepted public wireless services and wireless terminals in the Danish context for emergency warning of the general public . The results do not preclude the fact that alternative technologies and information handling techniques [13] may in the future offer a better impact with same or higher access terminal adoption .It has been shown that neither SMS nor Cell Broadcast based messaging meet all user requirements, although they meet most of them. The main drawback of an SMS based solution is the high risk of not being able to warn within 5 minutes due to network congestion and recipient selection overhead .The main drawback with Cell Broadcast is that the end user must in advance have configured his/her terminal or received a configuration patch via the wireless network or at sales time . Both systems offer potentially the needed flexibility.The risk and cost benefit analyses establish that the minimum numbers of reductions of deaths and injuries thanks to wireless warnings required for the systems to pay back over the years are likely to be met.The highest likelihood of meeting positive returns in view of all the expected diverse and cumulated threats in Denmark is met by the 15 years lifetime of an SMS based solution (2G or 3G) .Research issues remain as to the exact nature of end user driven emergency communication patterns and on faster decision making .

\section{REFERENCES}

1. FICORA, Use of text messaging in public safety alerts, WG report 7/2005, www.ficora.fi , 2005 
2. Beredskabsstyrelsen, Aftale om fremgangsmaaden ved udsendelse af beredskabdsmeddelelser (in Danish), www.beredskabsstyrelsen.dk , 2005

3. P. Simonsen, Katastrofevarsling til befolkningen via offentlige mobilnet (in Danish), Cand.merc.dat thesis, Copenhagen Business school, Copenhagen, 2007

4. ETSI, Analysis of the short message service (SMS) and Cell broadcast service (CBS) for emergency messaging applications, T 102444 v1.1.1, www.etsi.org , 2006

5. Cell broadcast Forum, Cell broadcast in public warning systems, www.cellbroadcastforum.org , 2007

6. M. Wood, Proposed request for comments on international cell alert via cell broadcasting channelization codes v3, CEASA, www.ceasa-int.org/channel_codes_v3.htm

7. London Assembly, Report of the 7 th July review committee, Greater London authority, www.london.gov.uk/assembly/reports/7july

8. Kolding Kommune, Spoergeskemaundersoegelse (in Danish), www.kolding.dk/printpage.asp?id=31377

9. C.T. Butts, M.Petrescu, B.R. Cross, Responder communication networks in the World Trade center disaster: implications for modelling of communication within emergency settings, J. Mathematical sociology, vol 31, no 2, 2007-05-12

10. B. Braunstein, Challenges in using distributed wireless mesh networks in emergency response, Proc. 3 rd Intl. ISCRAM Conference, Newark, NJ, May 2006, pp 58-64

11. S. Zhao , R. Addams-Moring, M. Kekkonen, Building mobile emergency announcement systems in 3 G networks, Proc. Communications and computer networks conference , ACTA Press, Calgary , Canada , 2005 , pp 141-148

12. Transport and Energi Ministry: Key figures catalogue for use for techno-economic analyses in the transport area, 4 th version, 2006 (in Danish) www.trm.dk/graphics/SynkronLibrary/trafikministeriet/Publikationer/Rapporter/Noegletalskatalog\%20juni\%202006.pdf

13. B. van de Walle, M. Turoff, Editors, Special issue: Emergency response information systems: emerging trends and technologies, Comm. ACM, vol 50, no 3, 2007, pp 28-65 


\section{Publications in the Report Series Research ${ }^{*}$ in Management}

\section{ERIM Research Program: "Business Processes, Logistics and Information Systems"}

2007

India: a Case of Fragile Wireless Service and Technology Adoption?

L-F Pau and J. Motiwalla

ERS-2007-011-LIS

http://hdl.handle.net/1765/9043

Some Comments on the Question Whether Co-occurrence Data Should Be Normalized

Ludo Waltman and Nees Jan van Eck

ERS-2007-017-LIS

http://hdl.handle.net/1765/9401

Extended Producer Responsibility in the Aviation Sector

Marisa P. de Brito, Erwin A. van der Laan and Brijan D. Irion

ERS-2007-025-LIS

http://hdl.handle.net/1765/10068

Logistics Information and Knowledge Management Issues in Humanitarian Aid Organizations

Erwin A. van der Laan, Marisa P. de Brito and S. Vermaesen

ERS-2007-026-LIS

http://hdl.handle.net/1765/10071

Bibliometric Mapping of the Computational Intelligence Field

Nees Jan van Eck and Ludo Waltman

ERS-2007-027-LIS

http://hdl.handle.net/1765/10073

Approximating the Randomized Hitting Time Distribution of a Non-stationary Gamma Process

J.B.G. Frenk and R.P. Nicolai

ERS-2007-031-LIS

http://hdl.handle.net/1765/10149

Application of a General Risk Management Model to Portfolio Optimization Problems with Elliptical Distributed Returns for Risk Neutral and Risk Averse Decision Makers

Bahar Kaynar, S. Ilker Birbil and J.B.G. Frenk

ERS-2007-032-LIS

http://hdl.handle.net/1765/10151

Optimal Zone Boundaries for Two-class-based Compact 3D AS/RS

Yugang Yu and M.B.M. de Koster

ERS-2007-034-LIS

http://hdl.handle.net/1765/10180

Portfolios of Exchange Relationships: An Empirical Investigation of an Online Marketplace for IT Services

Uladzimir Radkevitch, Eric van Heck and Otto Koppius

ERS-2007-035-LIS

http://hdl.handle.net/1765/10072

From Closed-Loop to Sustainable Supply Chains: The WEEE case

J. Quariguasi Frota Neto, G. Walther, J.Bloemhof, J.A.E.E van Nunen and T.Spengler

ERS-2007-036-LIS

http://hdl.handle.net/1765/10176 
A Methodology for Assessing Eco-Efficiency in Logistics Networks

J. Quariguasi Frota Neto, G. Walther, J.Bloemhof, J.A.E.E van Nunen and T.Spengler

ERS-2007-037-LIS

http://hdl.handle.net/1765/10177

Strategic and Operational Management of Supplier Involvement in New Product Development: a Contingency Perspective Ferrie E.A. van Echtelt, Finn Wynstra and Arjan J. van Weele

ERS-2007-040-LIS

http://hdl.handle.net/1765/10456

How Will Online Affiliate Marketing Networks Impact Search Engine Rankings?

David Janssen and Eric van Heck

ERS-2007-042-LIS

http://hdl.handle.net/1765/10458

Modelling and Optimizing Imperfect Maintenance of Coatings on Steel Structures

R.P. Nicolai, J.B.G. Frenk and R. Dekker

ERS-2007-043-LIS

http://hdl.handle.net/1765/10455

Human Knowledge Resources and Interorganizational Systems

Mohammed Ibrahim, Pieter Ribbers and Bert Bettonvil

ERS-2007-046-LIS

http://hdl.handle.net/1765/10457

Revenue Management and Demand Fulfilment: Matching Applications, Models, and Software

Rainer Quante, Herbert Meyr and Moritz Fleischmann

ERS-2007-050-LIS

http://hdl.handle.net/1765/10464

Mass Customization in Wireless Communication Services: Individual Service Bundles and Tariffs

Hong Chen and Louis-Francois Pau

ERS-2007-051-LIS

http://hdl.handle.net/1765/10515

Individual Tariffs for Mobile Services: Analysis of Operator Business and Risk Consequences

Hong Chen and Louis-Francois Pau

ERS-2007-052-LIS

http://hdl.handle.net/1765/10516

Individual Tariffs for Mobile Services: Theoretical Framework and a Computational Case in Mobile Music

Hong Chen and Louis-Francois Pau

ERS-2007-053-LIS

http://hdl.handle.net/1765/10517

Individual Tariffs for Mobile Communication Services

Hong Chen and Louis-Francois Pau

ERS-2007-054-LIS

http://hdl.handle.net/1765/10518

Is Management Interdisciplinary? The Evolution of Management as an Interdisciplinary Field of Research and Education in the Netherlands

Peter van Baalen and Luchien Karsten

ERS-2007-047-LIS

http://hdl.handle.net/1765/10537 
Detecting and Forecasting Economic Regimes in Multi-Agent Automated Exchanges Wolfgang Ketter, John Collins, Maria Gini, Alok Gupta and Paul Schrater

ERS-2007-065-LIS

http://hdl.handle.net/1765/10594

Emergency Messaging to General Public via Public Wireless Networks

P.Simonsen and L-F Pau

ERS-2007-078-LIS

http://hdl.handle.net/1765/10718

Flexible Decision Control in an Autonomous Trading Agent

John Collins, Wolfgang Ketter and Maria Gini

ERS-2007-079-LIS

http://hdl.handle.net/1765/10719

* A complete overview of the ERIM Report Series Research in Management: https://ep.eur.nl/handle/1765/1

ERIM Research Programs:

LIS Business Processes, Logistics and Information Systems

ORG Organizing for Performance

MKT Marketing

F\&A Finance and Accounting

STR Strategy and Entrepreneurship 